\title{
Have recent mass mortalities of the sardine Sardinops sagax facilitated an expansion in the distribution and abundance of the anchovy Engraulis australis in South Australia?
}

\author{
T. M. Ward*, F. Hoedt**, L. McLeay, W. F. Dimmlich***, G. Jackson****, P. J. Rogers, \\ K. Jones
}

South Australian Research and Development Institute (Aquatic Sciences), PO Box 120, Henley Beach, Adelaide, South Australia 5022, Australia

\begin{abstract}
This paper examines the hypotheses (1) that Sardinops sagax and Engraulis australis are spatially segregated and do not interact directly, and (2) that recent mass mortalities of $S$. sagax have facilitated an expansion in the distribution and abundance of E. australis. In South Australian waters, S. sagax and E. australis both spawn during summer and autumn. Eggs and larvae of both species occur over the continental shelf, and are abundant in areas where upwelling occurs (e.g. off the Coffin Bay Peninsula and the western tip of Kangaroo Island) and frontal systems form (e.g. in Investigator Strait and the entrance of Spencer Gulf). After the mass mortality events in 1995 and 1998, eggs and larvae of $S$. sagax were confined mainly to these areas, and estimates of the total abundance of S. sagax eggs and larvae in South Australian waters fell by between 48 and $83 \%$ respectively. Between 1996 and 1999, densities of E. australis eggs and larvae increased in both key spawning areas and the central and eastern Great Australian Bight, and total abundance of eggs and larvae increased by over 215 and $285 \%$ respectively. These results indicate that (1) S. sagax and E. australis are not spatially segregated and may interact directly, and (2) the mass mortalities of $S$. sagax may have facilitated an expansion in the distribution and abundance of E. australis. Hence, fluctuations in the relative abundance of $S$. sagax and Engraulis spp. observed in the world's productive boundary current systems may also be possible in Australian waters.
\end{abstract}

KEY WORDS: Sardine $\cdot$ Anchovy $\cdot$ Distribution and abundance $\cdot$ Eggs and larvae $\cdot$ Depth $\cdot$ Temperature $\cdot$ Spawning season $\cdot$ Spawning area $\cdot$ Competition

\section{INTRODUCTION}

The sardine Sardinops sagax and the anchovies Engraulis spp. dominate the clupeoid assemblages of

*E-mail: ward.tim@saugov.sa.gov.au

Present addresses:

**Department of Marine Biology and Aquaculture, James Cook University, Townsville, Queensland 4811, Australia

${ }^{* * *}$ Department of Environmental Biology, University of Adelaide, South Australia 5005, Australia

****Fisheries Western Australia, Western Australia Marine Research Laboratories, PO Box 120, North Beach, Western Australia 6020, Australia the productive coastal seas of the Kuroshio, Californian, Humbolt and Benguela boundary current systems, and the less productive waters of temperate and subtropical Australasia (Parrish et al. 1989). Fluctuations in the relative abundance of $S$. sagax and the local species of Engraulis have been recorded in Japan, California, Peru and South Africa, but not in Australia or New Zealand (Lluch-Belda et al. 1989, 1992a,b, Lluch-Cota et al. 1997, Schwartzlose et al. 1999). In a recent review of world-wide, large-scale fluctuations in the abundance of these genera, Schwartzlose et al. (1999) asserted that there may be 'almost no direct interaction' between sardine and anchovy in Australia, as the species are spatially segregated with $S$. sagax occur- 
Table 1. Sardinops sagax and Engraulis australis. Total numbers of samples and eggs and larvae collected during each month and each year. Number of positive (+ve) sites = number of sites in which eggs or larvae of each species were found. In 1997, S. sagax larvae and E. australis eggs and larvae were not counted

\begin{tabular}{|c|c|c|c|c|c|c|c|c|}
\hline \multirow[b]{2}{*}{ Year } & \multicolumn{4}{|c|}{ No. of samples } & \multicolumn{2}{|c|}{ S. sagax } & \multicolumn{2}{|c|}{ E. australis } \\
\hline & Jan & Feb & Mar & Total & $\begin{array}{l}\text { No. eggs } \\
\text { (+ve sites) }\end{array}$ & $\begin{array}{l}\text { No.larvae } \\
\text { (+ve sites) }\end{array}$ & $\begin{array}{l}\text { No. eggs } \\
\text { (+ve sites) }\end{array}$ & $\begin{array}{l}\text { No. larvae } \\
\text { (+ve sites) }\end{array}$ \\
\hline 1995 & 52 & - & 45 & 97 & 1197 (59) & $457(42)$ & $316(40)$ & 95 (27) \\
\hline 1996 & 64 & 90 & - & 154 & $116(43)$ & 135 (49) & $188(45)$ & $85(38)$ \\
\hline 1997 & - & 82 & 107 & 189 & $721(97)$ & - & - & - \\
\hline 1998 & - & 54 & 110 & 164 & $2738(110)$ & 1829 (127) & 495 (55) & $259(91)$ \\
\hline 1999 & - & 144 & 68 & 212 & $392(49)$ & 477 (83) & $2731(84)$ & 904 (145) \\
\hline
\end{tabular}

ring mainly over the continental shelf and the Australian anchovy E. australis found mostly in bays, inlets and estuaries.

Although the Australian population of Sardinops sagax is not known to have undergone fluctuations in abundance of the type observed in other ecosystems, it has been affected by 2 recent mass mortality events (Fletcher et al. 1997, Griffin et al. 1997, Hyatt et al. 1997, Jones et al. 1997, Whittington et al. 1997, Gaughan et al. 2000, Ward et al. 2001). These events occurred in 1995 and 1998/99, spread throughout the entire Australian range of the species and are thought to have killed more fish over a larger area than any other single-species fish-kill recorded (Jones et al. 1997). Several papers have discussed the nature of the disease agent and the spread of the 1995 event (Griffin et al. 1997, Hyatt et al. 1997, Jones et al. 1997, Whittington et al. 1997); however, few data have been published on the effects of the events on patterns of distribution and abundance (Fletcher et al. 1997, Gaughan et al. 2000, Ward et al. 2001). No previous study has investigated the hypothesis that these decreases in the abundance of $S$. sagax have facilitated expansions in the distribution and abundance of other planktivorous clupeoids, such as Engraulis australis.

South Australia lies at the centre of the Australian distribution of both Sardinops sagax and Engraulis australis, yet most studies of these species have been conducted off the eastern and western coasts of the continent (e.g. Fletcher et al. 1994, Hoedt \& Dimmlich 1995). Unlike the pelagic ecosystem off the eastern and western coasts, the hydrography of South Australia is not dominated by south-flowing, oligotrophic waters of tropical origin (Middleton 1995, Schwartzlose et al. 1999, Ward \& Staunton-Smith in press). Rather, productivity in shelf waters is enhanced during summer and autumn (December to April) by upwelling events that intrude into surface waters off the western Eyre Peninsula, around Cape Borda (Kangaroo Island) and along the state's south-eastern coastline (Lewis 1981, Griffin et al. 1997). In addition, planktonic organisms are concentrated during summer and autumn by frontal systems that form at the entrance of Spencer Gulf and in Investigator Strait (Bruce \& Short 1990). Not surprisingly, the spawning seasons of $S$. sagax and E. australis in South Australian waters coincide with the seasons during which these oceanographic phenomena occur (Ward unpubl. data).

Direct quantification of the distribution and abundance of small pelagic fishes is complicated by factors such as their highly aggregated distribution, extreme mobility and high capacity for net avoidance, temporal variations in their depth preferences and schooling behaviour, and difficulties in identifying species using remote-sensing techniques (Ward et al. 1998). Much of the data available on the patterns of distribution and abundance of Sardinops sagax and Engraulis spp. in other ecosystems have been obtained from ichthyoplankton surveys (Smith 1973, 1990, Crawford 1981a,b, Lasker 1985).

This paper describes and compares the distribution and abundance of the eggs and larvae of Sardinops sagax and Engraulis australis in South Australia. Findings are used to examine the hypotheses that (1) these species are spatially segregated and do not interact directly in Australian waters and (2) the decline in the abundance of $S$. sagax resulting from 2 mass mortality events has facilitated an expansion in the distribution and abundance of E. australis.

\section{MATERIALS AND METHODS}

Plankton surveys. Each year between 1995 and 1999, plankton samples were collected during January to March from sites located throughout South Australian waters (Table 1, Fig. 1). A total of 816 samples was collected using paired CalVet nets $(0.225 \mathrm{~m}$ diameter, $500 \mu \mathrm{m}$ mesh) towed vertically at approximately $1 \mathrm{~m} \mathrm{~s}^{-1}$. Nets were deployed to within $10 \mathrm{~m}$ of the seabed in waters less than $80 \mathrm{~m}$ deep and to a depth of $70 \mathrm{~m}$ in waters deeper than $80 \mathrm{~m}$. The distance travelled by each net was estimated using flowmeters. The volume of water filtered was calculated by multiplying 

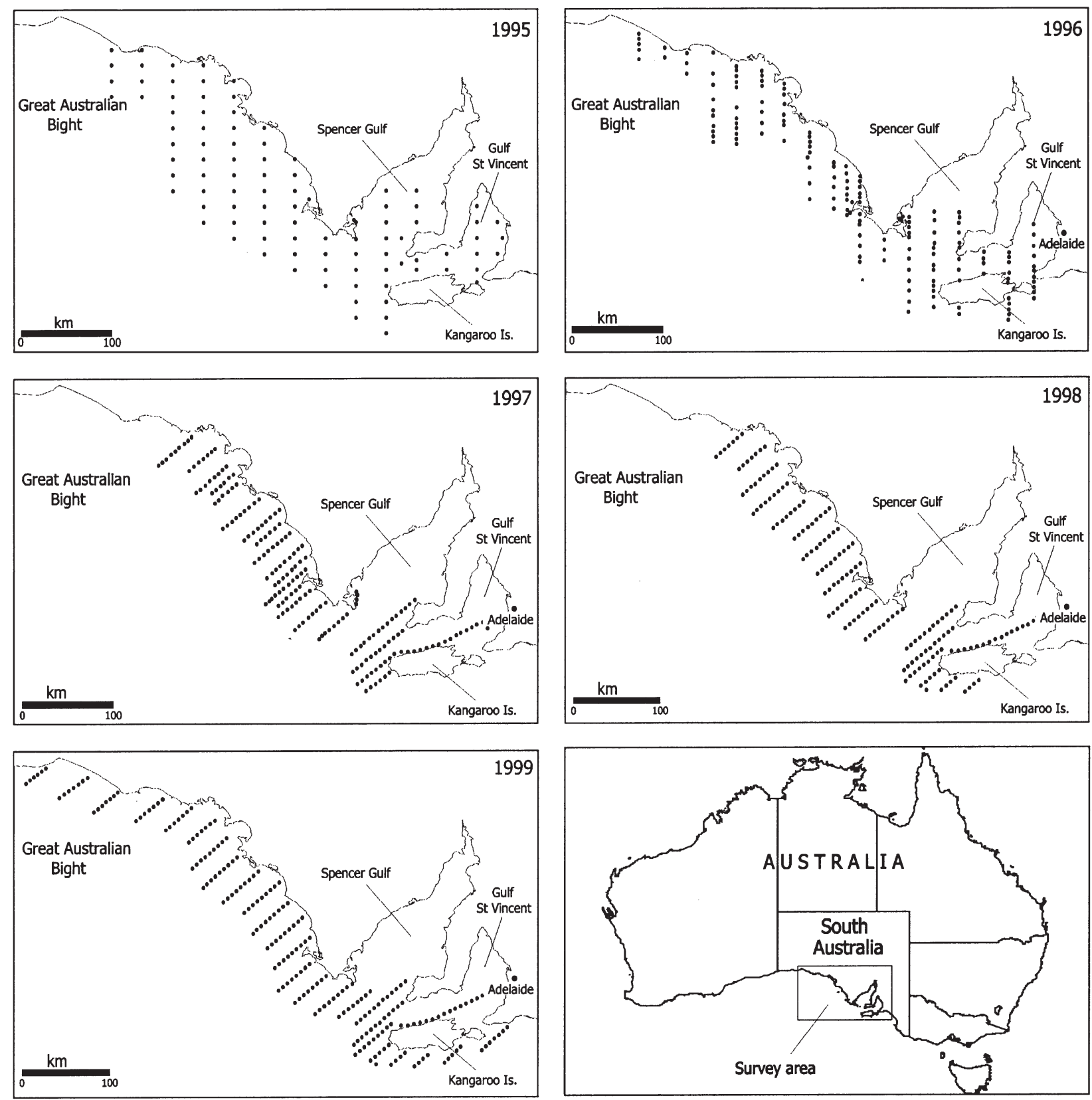

Fig. 1. Maps showing locations referred to in text, and sites at which plankton samples were collected in South Australia between 1995 and 1999. Dots indicate stations along sampling transects

the distance towed by the surface area of the net. Depth and sea surface temperature were recorded at each site. Samples were stored in $5 \%$ formaldehyde.

Laboratory analyses. Plankton samples were rinsed of formalin and sorted using a dissecting microscope. Eggs and larvae of Sardinops sagax and Engraulis australis were identified using standard references (e.g. Lasker 1985, Gaughan et al. 1996, Neira et al. 1998). In 1997, S. sagax larvae and E. australis eggs and larvae were not enumerated.
Data analysis. The density (per $100 \mathrm{~m}^{3}$ ) of Sardinops sagax and Engraulis australis eggs and larvae in each sample $\left(D_{V}\right)$ was calculated using the equation: $D_{V}=$ $(100 \times N) / V$, where $N$ is the total of eggs/larvae in each sample and $V$ is the volume of water sampled $\left(\mathrm{m}^{3}\right)$.

A $\ln (x+1)$ transformation was used to normalise the distributions of egg and larval densities. To overcome inter-annual changes in the sampling regime, each site was assigned to a $6 \times 6$ nautical mile grid-square. Effects of grid-square, depth, temperature, month and 
Table 2. Sardinops sagax and Engraulis australis. Total sampling area and estimated total area in which eggs and larvae were present. Estimates of total area of occurrence for 1999 only take into account sites that were also sampled in 1998

\begin{tabular}{|cccccc|}
\hline \multirow{2}{*}{ Year } & \multirow{2}{*}{$\begin{array}{c}\text { Sampling } \\
\text { area }\left(\mathrm{km}^{2}\right)\end{array}$} & \multicolumn{2}{c|}{ S. sagax } & \multicolumn{2}{c|}{ E. australis } \\
& & & Larvae & Eggs & Larvae \\
\hline 1995 & 111719 & 69375 & 51478 & 45610 & 33834 \\
1996 & 76070 & 17990 & 21841 & 19880 & 17394 \\
1997 & 49825 & 26275 & - & - & - \\
1998 & 49405 & 33801 & 39928 & 18413 & 24090 \\
1999 & 67653 & 11436 & 21366 & 17690 & 32986 \\
\hline
\end{tabular}

year on egg and larval densities were examined using univariate general linear models with Type III sums of squares.

To calculate the total abundance of eggs and larvae of each species in each year, the survey area was divided into a series of contiguous polygons approximately centred on each site. The size of each polygon
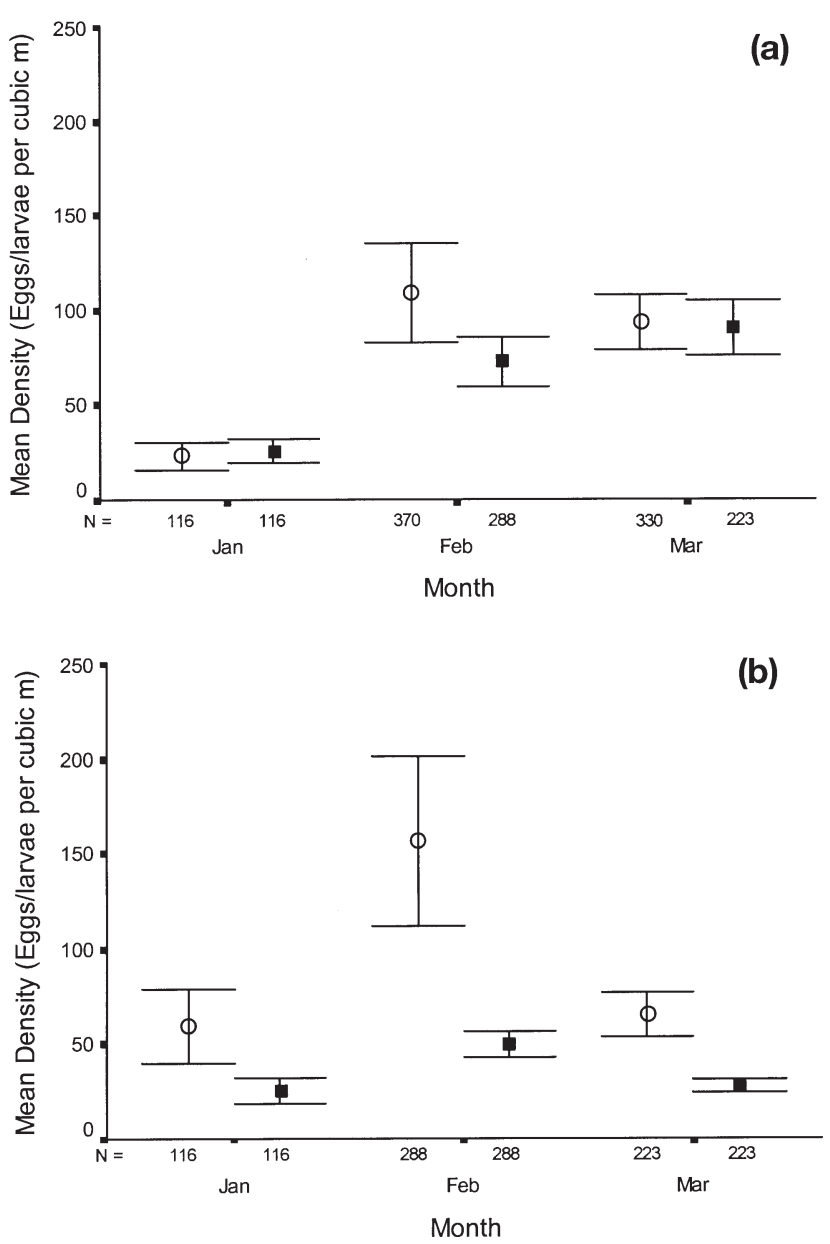

Fig. 2. (a) Sardinops sagax and (b) Engraulis australis. Mean monthly densities ( \pm SE) of eggs $(O)$ and larvae ( $\mathbf{\square})$ in South Australia was determined using geographical information software $\left(\right.$ Mapinfo ${ }^{\odot}$ ). The density $\left(\right.$ per $\mathrm{km}^{2}$ ) of the eggs and larvae of each species in each polygon $\left(D_{a}\right)$ was estimated according to the equation: $D_{a}=(N / V) \times \mathrm{M} \times 10^{6}$ where $M$ is depth in metres for sites located in less than $70 \mathrm{~m}$ of water and $70 \mathrm{~m}$ for deeper sites. Weighted mean $D_{a}$ in grids containing eggs/larvae were calculated by weighting the density for each grid by its area. Total egg/larval abundance for each species in each year in each state was estimated by multiplying weighted mean $D_{a}$ by the sum of the area of the grids that contained those eggs/larvae.

\section{RESULTS}

\section{Total sample}

The sampling strategy and size of area sampled varied between years (Fig. 1). In 1995, the primary goal was to identify the extent of the spawning grounds of Sardinops sagax, and so a large area $\left(111719 \mathrm{~km}^{2}\right)$ containing relatively few sites (97) was sampled (Tables 1 \& 2, Fig. 1). In 1996, the size of sampling area was reduced to $76070 \mathrm{~km}^{2}$ but more samples (154) were collected. From 1997 onwards, transects were orientated in a NE-SW (cf. North-South) direction, sampling was confined to key spawning areas, and between 164 and 212 samples were collected (Tables 1 \& 2, Fig. 1).

Totals of 5164 eggs and 2898 larvae of Sardinops sagax and 3730 eggs and 1343 larvae of Engraulis australis were collected (Table 1). Higher numbers of $S$. sagax eggs and larvae were collected in 1995 and 1998, the years immediately preceding the mortality events, whereas higher numbers of E. australis eggs and larvae were collected in 1998 and 1999, the last 2 years of the study (Table 1). In contrast, relatively low numbers of $S$. sagax eggs and larvae were collected in 1996 and 1999, the years immediately following the mortality events, whereas relatively low numbers of $E$. australis eggs and larvae were collected during the first 2 yr of the study (Table 1).

\section{Month}

Although relatively low densities of eggs and larvae of both species were recorded during January (Fig. 2), the effect of month on mean densities was statistically significant for Engraulis australis eggs only (Tables 1 \& 3). The lower than expected densities of eggs and larvae of both species collected in 1995, may reflect the fact that most sampling in that year was conducted during January (i.e. prior to the peak spawning season) (Table 1). 
Table 3. Sardinops sagax and Engraulis australis. Results of univariate general linear model of mean transformed densities of eggs and larvae. Degrees of freedom, mean squares (in italics) and F-values are given above p-values. Significant p-values are in bold-face

\begin{tabular}{|c|c|c|c|c|c|c|c|}
\hline Species & Grid & Depth & Temp & Month & Year & Corrected model & Error \\
\hline \multicolumn{8}{|l|}{ S. sagax } \\
\hline 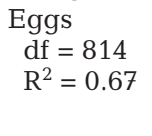 & $\begin{array}{c}415 \\
4.605 \\
1.20 \\
\mathbf{0 . 0 3 7}\end{array}$ & $\begin{array}{c}13 \\
6.826 \\
0.78 \\
\mathbf{0 . 0 4 5}\end{array}$ & $\begin{array}{c}9 \\
10.839 \\
2.83 \\
\mathbf{0 . 0 0 3}\end{array}$ & $\begin{array}{c}2 \\
2.315 \\
0.603 \\
0.548\end{array}$ & $\begin{array}{c}4 \\
55.048 \\
15.127 \\
<\mathbf{0 . 0 0 0 1}\end{array}$ & $\begin{array}{c}448 \\
6.322 \\
1.1 .647 \\
<\mathbf{0 . 0 0 0 1}\end{array}$ & $\begin{array}{c}365 \\
3.837\end{array}$ \\
\hline $\begin{array}{l}\text { Larvae } \\
\begin{aligned} \mathrm{df} & =625 \\
\mathrm{R}^{2} & =0.77\end{aligned}\end{array}$ & $\begin{array}{c}371 \\
3.899 \\
1.19 \\
\mathbf{0 . 0 7 6}\end{array}$ & $\begin{array}{c}12 \\
2.238 \\
0.68 \\
0.767\end{array}$ & $\begin{array}{c}9 \\
9.029 \\
2.76 \\
\mathbf{0 . 0 0 4}\end{array}$ & $\begin{array}{c}2 \\
0.197 \\
0.60 \\
0.942\end{array}$ & $\begin{array}{c}3 \\
51.823 \\
15.823 \\
<\mathbf{0 . 0 0 0 1}\end{array}$ & $\begin{array}{c}403 \\
6.035 \\
1.843 \\
<\mathbf{0 . 0 0 0 1}\end{array}$ & $\begin{array}{c}221 \\
3.247\end{array}$ \\
\hline \multicolumn{8}{|l|}{ E. australis } \\
\hline $\begin{array}{l}\text { Eggs } \\
\qquad \begin{array}{l}\mathrm{df}=625 \\
\mathrm{R}^{2}=0.68\end{array}\end{array}$ & $\begin{array}{c}371 \\
4.582 \\
0.98 \\
0.588\end{array}$ & $\begin{array}{c}12 \\
5.407 \\
1.15 \\
0.321\end{array}$ & $\begin{array}{c}9 \\
11.484 \\
2.44 \\
\mathbf{0 . 0 1 1}\end{array}$ & $\begin{array}{c}2 \\
16.343 \\
3.48 \\
\mathbf{0 . 0 3 3}\end{array}$ & $\begin{array}{c}3 \\
26.477 \\
5.63 \\
\mathbf{0 . 0 0 1}\end{array}$ & $\begin{array}{c}403 \\
5.552 \\
1.81 \\
\mathbf{0 . 0 8 3}\end{array}$ & $\begin{array}{c}221 \\
4.700\end{array}$ \\
\hline $\begin{array}{l}\text { Larvae } \\
\mathrm{df}=625 \\
\mathrm{R}^{2}=0.65\end{array}$ & $\begin{array}{c}371 \\
3.187 \\
0.93 \\
0.743\end{array}$ & $\begin{array}{c}12 \\
2.794 \\
0.81 \\
0.638\end{array}$ & $\begin{array}{c}9 \\
3.280 \\
0.95 \\
0.480\end{array}$ & $\begin{array}{c}2 \\
0.480 \\
0.14 \\
0.870\end{array}$ & $\begin{array}{c}3 \\
18.192 \\
5.29 \\
\mathbf{0 . 0 0 2}\end{array}$ & $\begin{array}{c}403 \\
4.418 \\
1.28 \\
\mathbf{0 . 0 0 0 1}\end{array}$ & $\begin{array}{c}221 \\
3.442\end{array}$ \\
\hline
\end{tabular}

\section{Depth}

Large numbers of eggs and larvae of both species were collected from sites located in depths between 20 and $140 \mathrm{~m}$ (Fig. 3), and the depth in which a site was located was not an important determinant of egg or larval density of either species (Table 3).

\section{Sea surface temperature}

Eggs and larvae of Sardinops sagax and Engraulis australis were collected commonly from sites with sea surface temperatures (SSTs) ranging from 15.5 to $23.5^{\circ} \mathrm{C}$, and mean densities were high in sites with SSTs between 15.5 and $17.5^{\circ} \mathrm{C}$ and between 19.5 and $22.5^{\circ} \mathrm{C}$ (Fig. 4, Table 3).

\section{Spatial distribution}

In 1995 and 1998, the years immediately preceding the mass mortality events, Sardinops sagax eggs were obtained from approximately $60 \%$ of sites, and sites containing eggs were located throughout the

Fig. 3. (a) Sardinops sagax and (b) Engraulis australis. Effect of depth on mean densities $( \pm \mathrm{SE})$ of eggs $(\mathrm{O})$ and larvae in South Australia
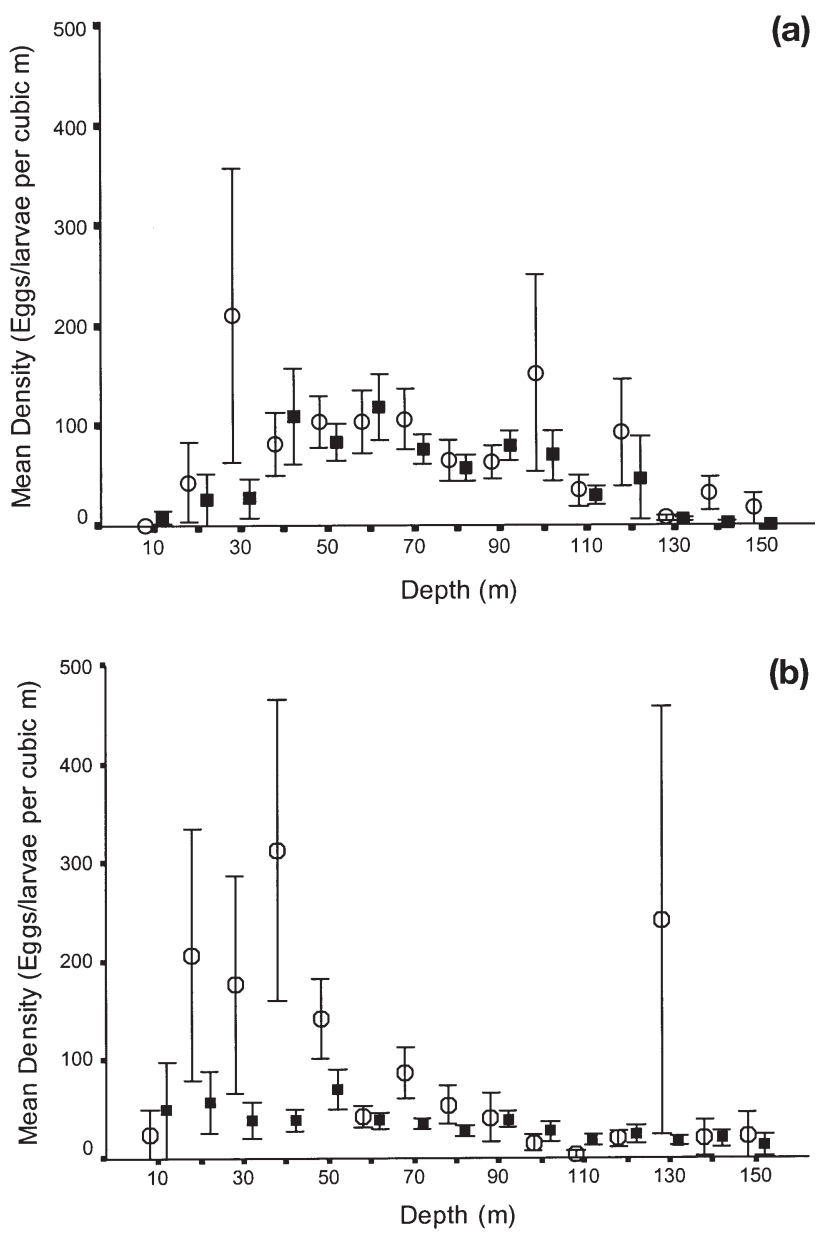

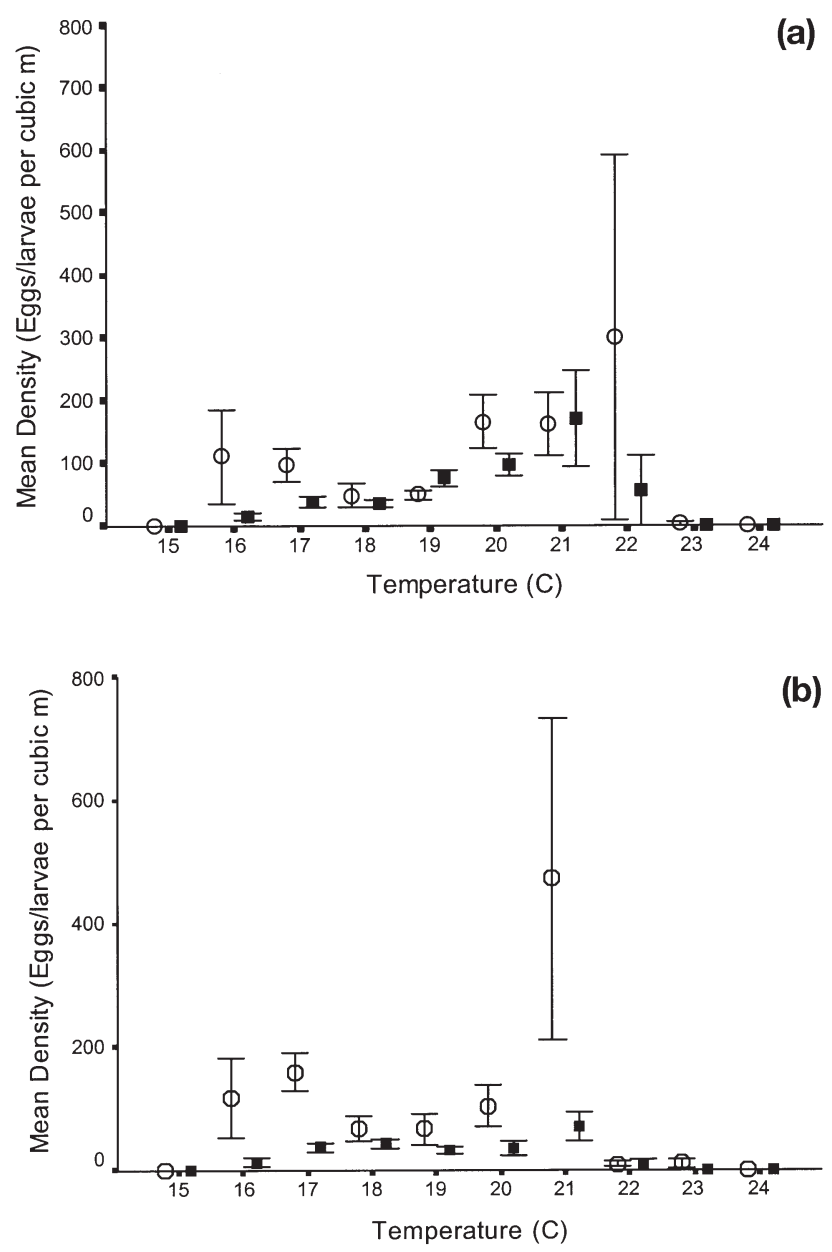

Fig. 4. (a) Sardinops sagax and (b) Engraulis australis. Effect of sea surface temperature on mean densities (+ $\mathrm{SE}$ ) of eggs (O) and larvae (ם) in South Australia

survey area (Table 1, Fig. 5). The relatively small numbers of eggs collected in sites east of Coffin Bay Peninsula in 1995 may reflect the fact that these sites were sampled during January, i.e. prior to the peak spawning season. In 1996 and 1999, the years immediately following the mass mortality events, S. sagax eggs were obtained from $<30 \%$ of sites (Table 1 , Fig. 5); few S. sagax eggs and larvae were collected from the central and eastern Great Australian Bight (Figs. 5 \& 6). In 1996, most $S$. sagax eggs and larvae were collected from sites off the Coffin Bay Peninsula and the western tip of Kangaroo Island and in Investigator Strait and the entrance to Spencer Gulf. In 1999, egg and larval densities were again relatively high at sites near Cape Borda and in Investigator Strait and the entrance to Spencer Gulf, but few eggs or larvae were collected from stations near the Coffin Bay Peninsula, where the fishery is centred (Ward et al. 1998).
Eggs and larvae of Engraulis australis were collected from 29 and $25 \%$ of sites respectively in 1996 and 39 and $68 \%$ of sites respectively in 1999 (Table 1, Figs. 7 $\&$ 8). In 1995, when sites east of the Coffin Bay Peninsula were sampled during January, few E. australis eggs or larvae were obtained from this area. In 1996, E. australis eggs or larvae were collected mainly from sites near the Coffin Bay Peninsula, the western tip of Kangaroo Island, Investigator Strait and the entrances of Spencer Gulf and Gulf St. Vincent (Figs. 7 \& 8). In contrast, during 1998 and 1999, E. australis eggs and larvae were also highly abundant at sites located in the central and eastern Great Australian Bight.

\section{Mean density}

The effect of the second mass mortality event can be seen in the $60 \%$ decrease in the mean density of Sardinops sagax eggs from 360 ( \pm 78 SE) eggs per $100 \mathrm{~m}^{3}$ in 1998 to $148( \pm 32 \mathrm{SE})$ eggs per $100 \mathrm{~m}^{3}$ in 1999. Similarly, between 1998 and 1999 the mean density of $S$. sagax larvae fell by $50 \%$ from $208( \pm 30 \mathrm{SE})$ to 99 ( $\pm 11 \mathrm{SE}$ ) larvae per $100 \mathrm{~m}^{3}$ (Fig. 9). The effect of the first mortality event on mean density of $S$. sagax eggs and larvae was difficult to discern, perhaps because in 1995 many samples were collected in early January, prior to the peak spawning season, and the estimate of mean egg density for that year was thus negatively biased.

The scheduling of the first sampling cruise also affected estimates of the mean density of Engraulis australis eggs and larvae for 1995. It is therefore more appropriate to examine changes in mean density by comparing estimates for 1996 and 1999. Between these years, mean densities of E. australis eggs and larvae increased by $315 \%$, from $138( \pm 25 \mathrm{SE})$ to 572 ( $\pm 9 \mathrm{SE})$ eggs per $100 \mathrm{~m}^{3}$ and by $30 \%$ from $81( \pm 79 \mathrm{SE})$ to 105 ( $\pm 12 \mathrm{SE}$ ) larvae per $100 \mathrm{~m}^{3}$ (Fig. 9).

\section{Total abundance}

Underestimation of egg and larval densities for 1995 resulting from the timing of the first research cruise ensures that estimates of the effect of the first mortality event are conservative. Between 1995 and 1996, estimates of total abundance of eggs and larvae of Sardinops sagax declined by 77 and $48 \%$ respectively. Estimates of the area in which eggs and larvae were present during 1999 were based only on sites that were also sampled in 1998. Between 1998 and 1999 estimates of the total abundance of $S$. sagax eggs and larvae fell by 83 and $78 \%$ respectively (Fig. 10). 

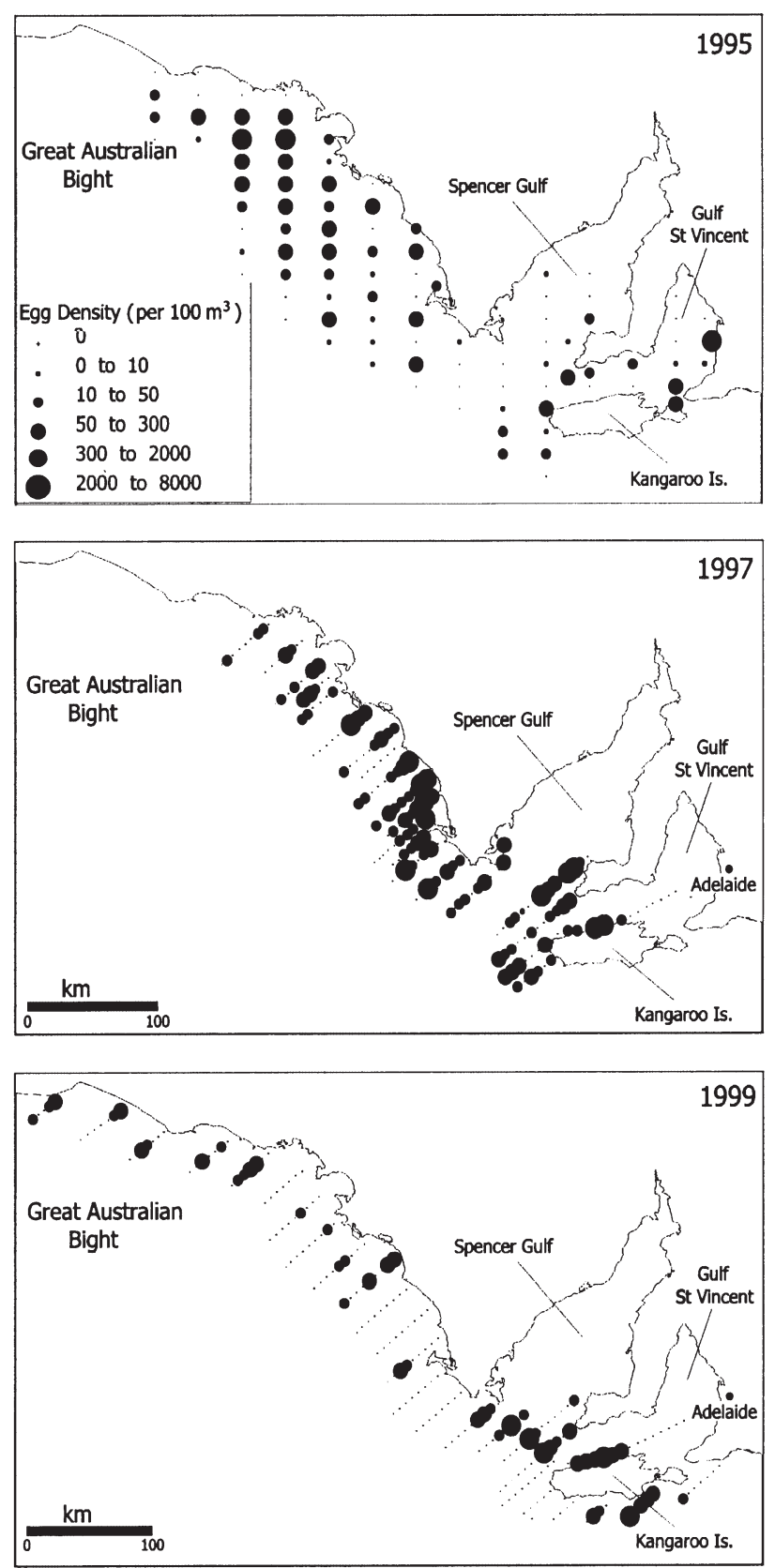

Between 1996 and 1999, estimates of the total abundance of Engraulis australis eggs and larvae increased by approximately 286 and $215 \%$ respectively (Fig. 10).

\section{DISCUSSION}

The assertion by Schwartzlose et al. (1999) that in Australia Sardinops sagax and Engraulis australis are spatially segregated, with $S$. sagax occurring mainly over the continental shelf and E. australis found mostly in bays, inlets and estuaries, appears to be incorrect.
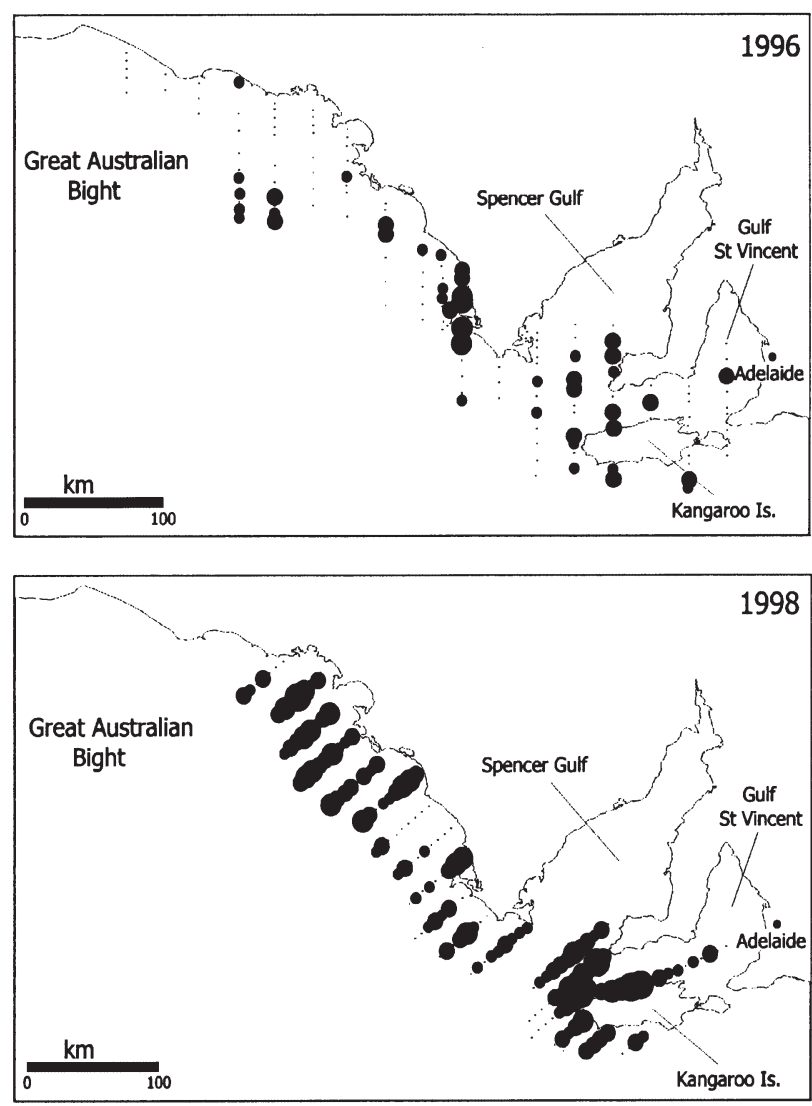

Fig. 5. Sardinops sagax. Density of eggs in South Australia during 1995 to 1999

The eggs and larvae of both species are found throughout shelf waters of South Australia, and at sites located in a wide range of depths (Fig. 3). Hoedt \& Dimmlich (1995) also found eggs and larvae of both species in shelf waters off Victoria. It is thus clear that, like most other species of Engraulis (e.g. McGowan 1986, Vouglitous et al. 1987), E. australis inhabits waters of the continental shelf as well as bays, inlets and estuaries.

Evidence suggesting that Sardinops sagax and Engraulis australis both spawn in a wide range of temperatures is consistent with findings obtained in other studies of these genera (e.g. Lluch-Belda et al. 1991). The dual peaks in the spawning activity of $S$. sagax at temperatures of 15 and $23^{\circ} \mathrm{C}$ observed in the California Current (Lluch-Belda et al. 1991) are remarkably similar to the bi-modal pattern of egg abundance suggested by data obtained in the present study (Fig. 4). In contrast, Lluch-Belda et al. (1991) observed only 1 spawning maximum for E. mordax, whereas data presented here for E. australis suggest the possibility of bimodality. The occurrence of dual peaks in spawning activity is surprising, as the optimum spawning temperature would be expected to occur around the mid- 

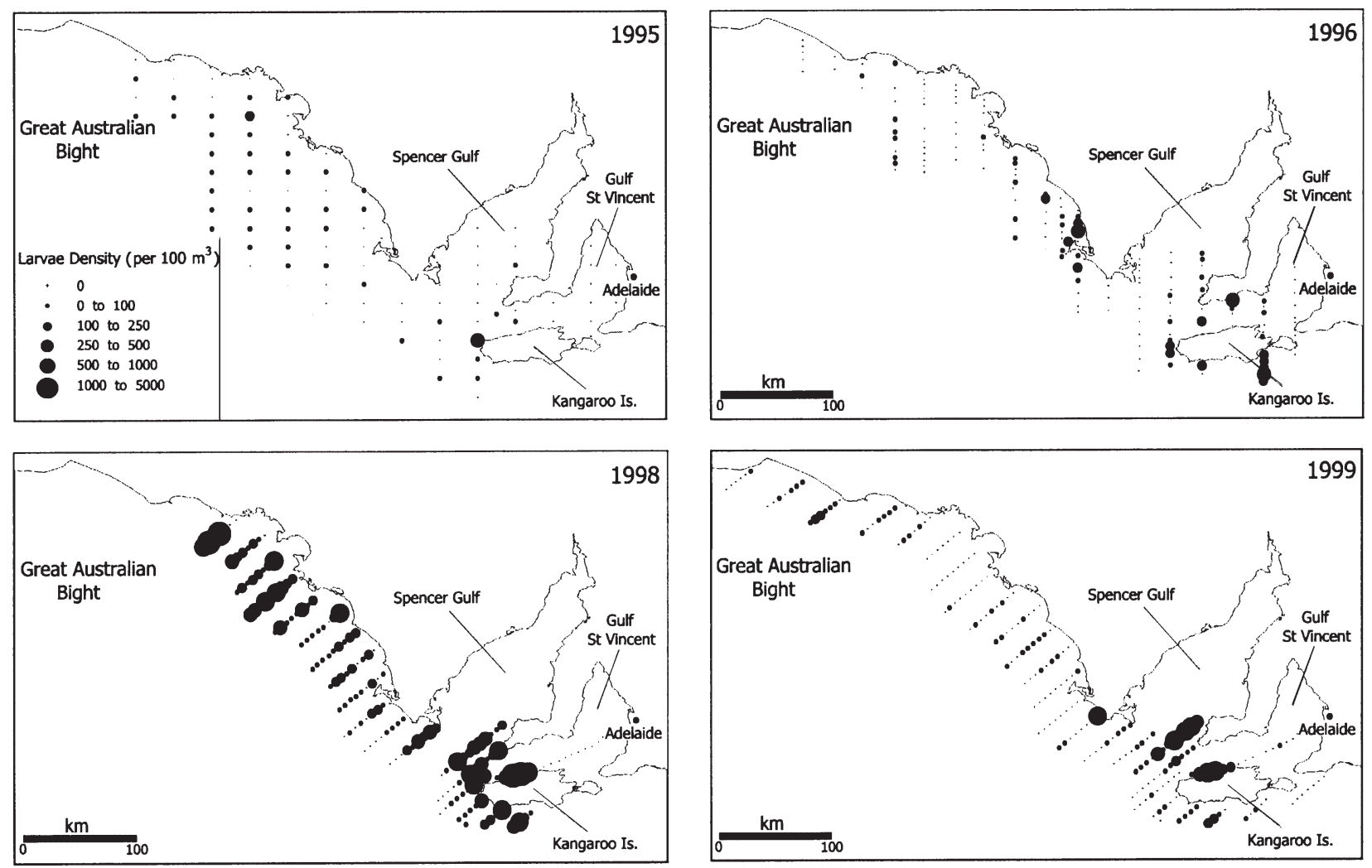

Fig. 6. Sardinops sagax. Density of S. sagax larvae in South Australia during 1995 to 1999
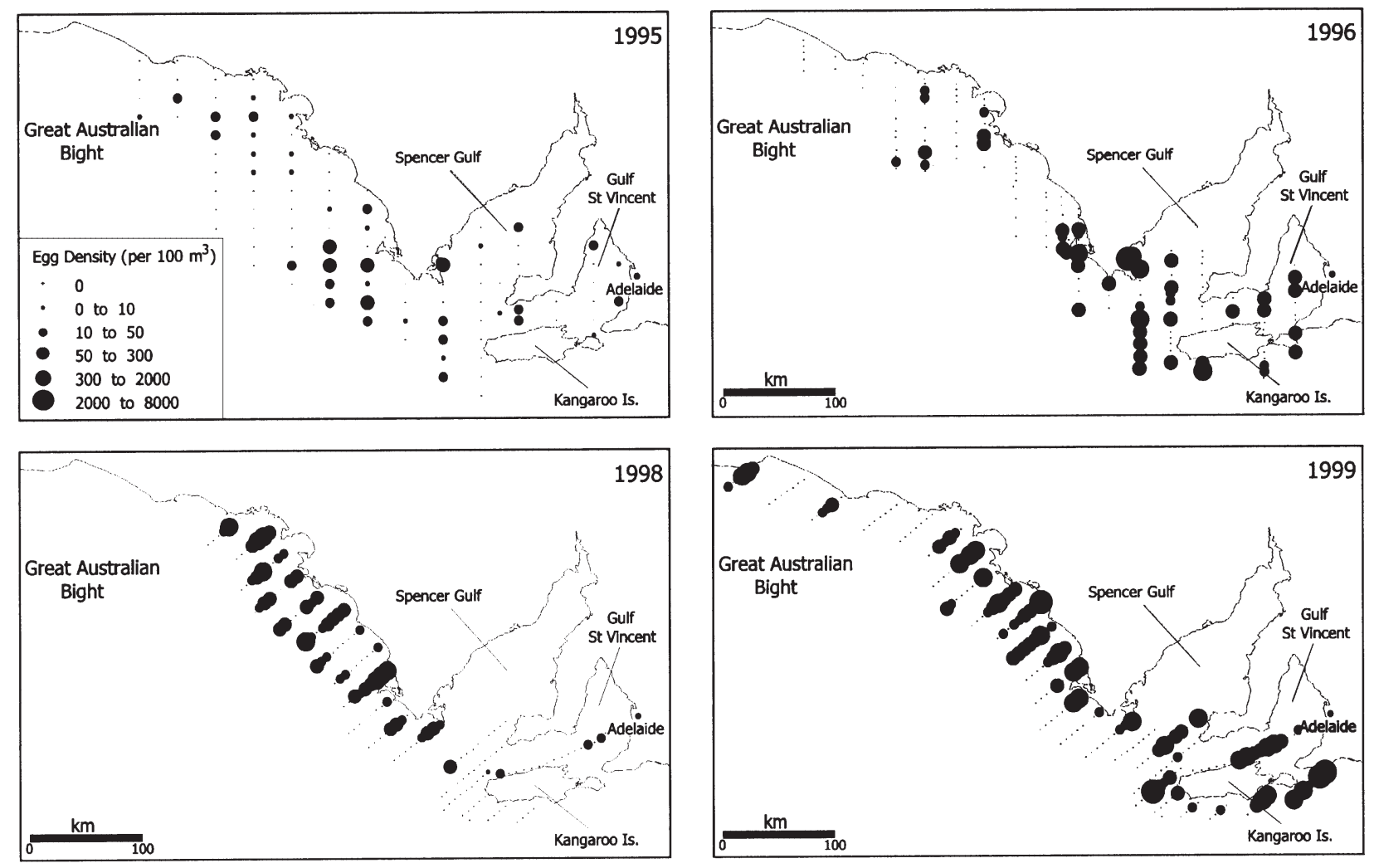

Fig. 7. Engraulis australis. Density of eggs in South Australia during 1995 to 1999 

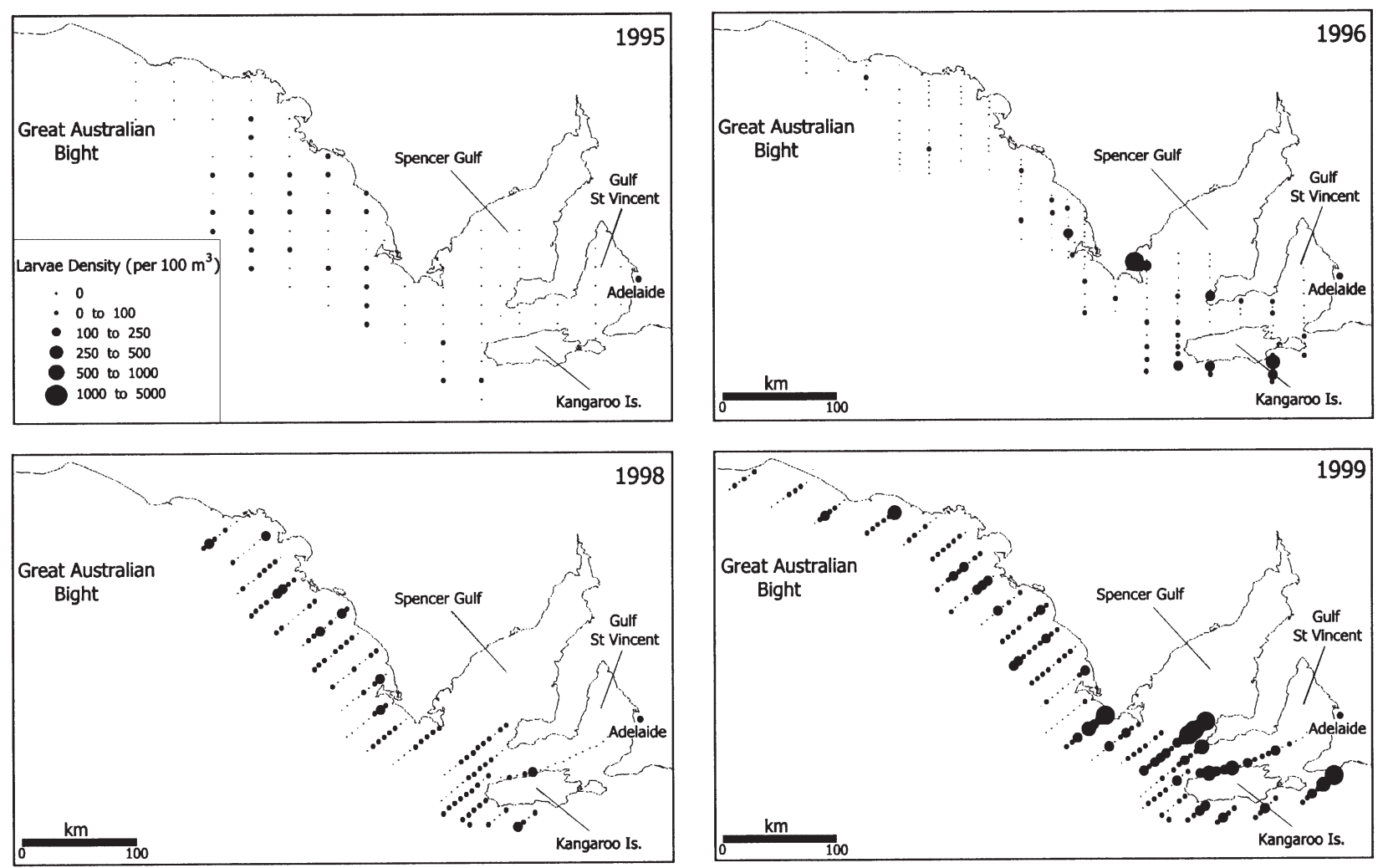

Fig. 8. Engraulis australis. Density of larvae in South Australia during 1998 to 1999

point between the extremes. Lluch-Belda et al. (1991) suggested that this hiatus may be related to upwelling. As the spawning seasons of $S$. sagax and E. australis coincide with months during which upwelling occurs and important spawning grounds for both species are located near upwelling areas such a link may also explain the patterns observed in South Australia.

The contraction, following the 2 mass mortality events, of spawning activity of Sardinops sagax into areas where upwelling occurs (e.g. off the Coffin Bay Peninsula and the western tip of Kangaroo Island) and frontal systems form (e.g. Investigator Strait and the entrance of Spencer Gulf) emphasises the importance of these locations for S. sagax in South Australia. The relatively low abundance during 1998 and 1999 of $S$. sagax eggs and larvae in waters around the Coffin Bay Peninsula, where the fishery is centred, provides evidence of the increased vulnerability to over-fishing of stocks that have been affected by mass mortality events (Ward \& Staunton-Smith in press). These observations emphasise the need to establish conservative quotas in the years immediately following such events and the value of incorporating closure areas that include key spawning grounds into strategies for managing stocks of pelagic fishes.

The coincidental timing of the expansion of the Engraulis australis population and the declines in the abundance of Sardinops sagax resulting from the mortality events suggest that these species compete for resources. This interpretation contradicts the assertion by Schwartzlose et al. (1999) that there may be 'almost no direct interaction' between these genera in Australia, but is consistent with observations of these genera in other ecosystems (Lluch-Belda et al. 1992a,b). As appears to be the case in the Californian Current (Lluch-Belda et al. 1991), S. sagax seems to dominate the interaction.

Increases between 1996 and 1999 in estimates of the total abundance of Engraulis australis eggs and larvae reflect increases both in the areas occupied and in mean densities. The expansion of the distribution of E. australis into waters of the eastern Great Australian Bight is notable, as Schwartzlose et al. (1999, p 305) suggested that this species is 'not found in the GAB (Great Australian Bight)'. The increases in egg and larval density are also significant, as several other studies of these species have suggested that changes in total abundance are more usually reflected in changes in spawning area than changes in density (e.g. Smith 1990).

The apparent increase in the abundance of Engraulis australis does not provide unequivocal proof that longterm changes in the total and relative abundance of Sardinops sagax and E. australis have or will occur in Australia; a much longer time series of data would be 

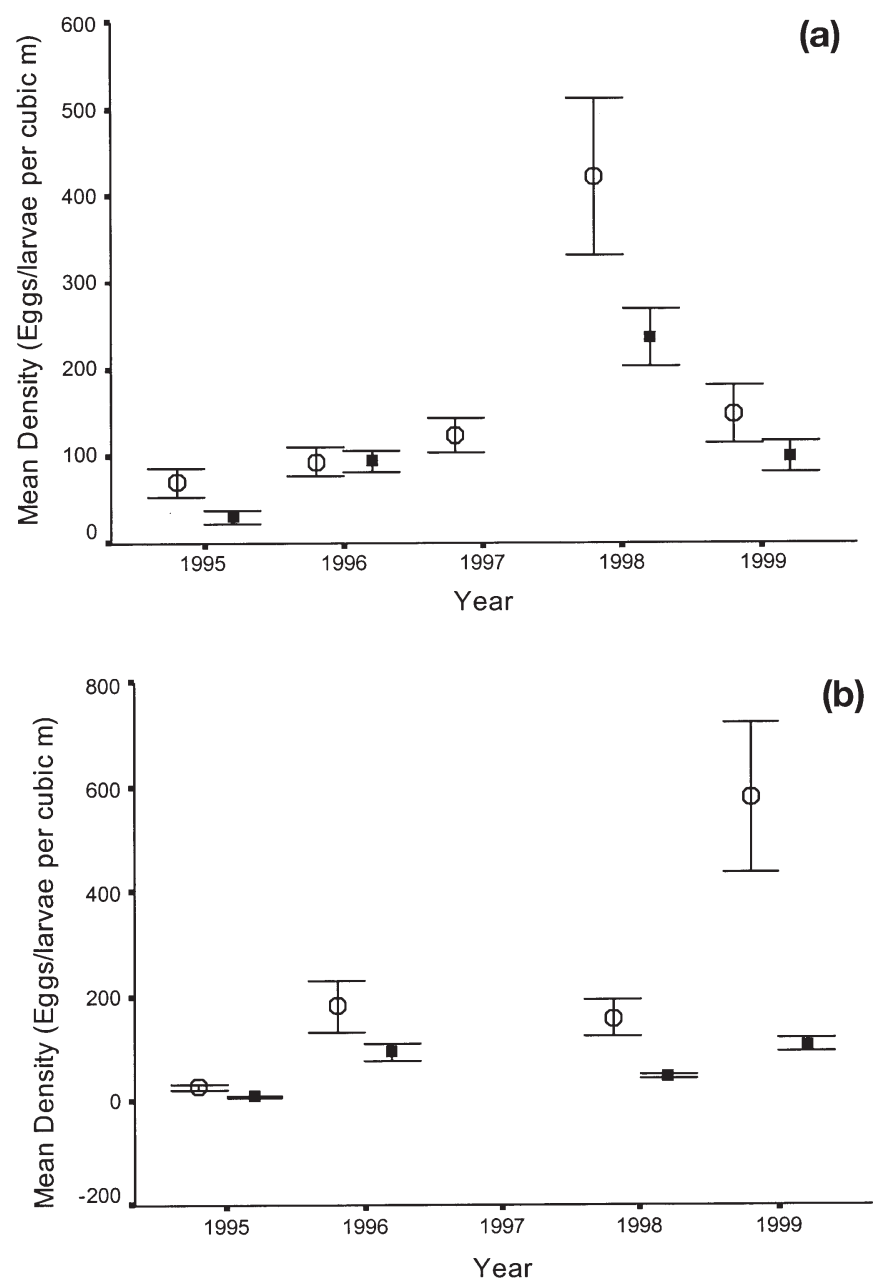

Fig. 9. (a) Sardinops sagax and (b) Engraulis australis. Mean density of eggs (O) and larvae (ם) in positive sites in South Australia between 1995 and 1999
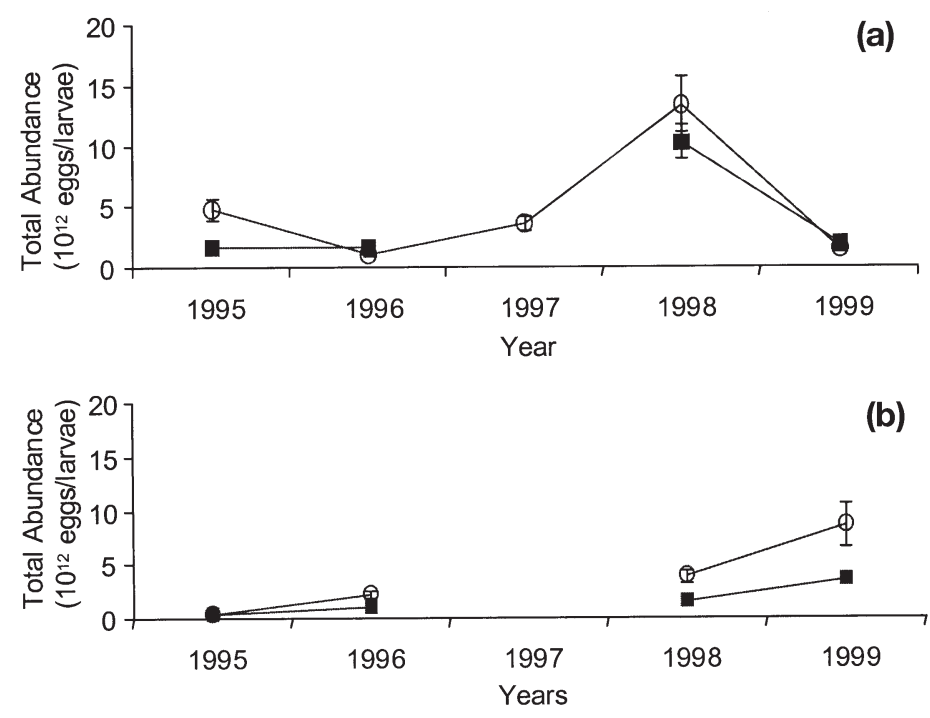

Fig. 10. (a) Sardinops sagax and (b) Engraulis australis. Estimates of the total abundance of eggs (O) and larvae ( $\mathbf{0})$ in South Australian waters between 1995 and 1996 required to assess this proposition. However, the data presented here do provide compelling evidence that these species occupy similar environments, interact directly and may undergo fluctuations in abundance of the type observed in the boundary current systems. Like the changes in abundance observed elsewhere, these fluctuations have the potential to alter the structure and function of pelagic ecosystems, and may affect populations of some predatory marine species adversely (Ward et al. 1998).

Unlike the fluctuations in the relative abundance of Sardinops spp. and Engraulis spp. observed in the boundary current systems, the changes described here may have been induced by human activities (e.g. Gaughan et al. 2000). Numerous papers and reports have suggested that imported frozen $S$. sagax used as fodder in the tuna mariculture industry is a potential source of the herpes virus(es) that caused the mass mortality events (Griffin et al. 1997, Jones et al. 1997, Gaughan et al. 2000, Ward et al. 2001). This link remains unproven, but the potential effects of such events on the structure and function of Australia's pelagic ecosystem are serious. Conservation and biodiversity legislation in many countries, including Australia, calls for a precautionary approach to the management of serious risks. A precautionary approach to risk assessment conflicts with the approach of the 'Office International des Epizooties', which requires importing countries to prove that there is a potential risk of introducing a specific disease before the importation of untreated fish products can be restricted (e.g. Gaughan et al. 2000, Jones in press).

\section{LITERATURE CITED}

Bruce BD, Short DA (1990) Observations on the distribution of larval fish in relation to a frontal zone at the mouth of Spencer gulf, South Australia. Bur Rur Resour Proc 15:124-137

Crawford RJM (1981a) Distribution availability and movements of pilchard Sardinops ocellata off South Africa. Fish Bull S Afr 14:1-46

Crawford RJM (1981b) Distribution availability and movements of anchovy Engraulis capenisis off South Africa. Fish Bull S Afr 14:51-94

Fletcher WJ, Tregonning RJ, Sant GJ (1994) Interseasonal variation in the transport of pilchard eggs and larvae off southern Western Australia. Mar Ecol Prog Ser 111:209-224

Fletcher WJ, Jones B, Pearce AF, Hosja W (1997) Environmental and biological aspects of the mass mortality of pilchards (autumn 1995) in 
Western Australia. West Aust Fish Dep Fish Res Rep 106:1-112

Gaughan DJ, Fletcher WJ, Tregonning RJ, Goh J (1996) Aspects of the biology and stock assessment of the whitebait, Hyperlophus vittatus, in South Western Australia. West Aust Fish Dep Fish Res Rep 108:1-127

Gaughan DJ, Mitchell RW, Blight SJ (2000) Impact of mortality due to herpesvirus on pilchard Sardinops sagax along the south coast of Western Australia in 1998-1999. Mar Freshw Res 51:601-612

Griffin DA, Thompson PA, Bax NJ, Hallegraeff, GM (1997) The 1995 mass mortality of pilchards: no role found for physical or biological oceanographic factors in Australia. Mar Freshw Res 48:27-58

Hoedt FE, Dimmlich WF (1995) Egg and larval abundance and spawning localities of the anchovy (Engraulis australis) and pilchard (Sardinops neopilchardus) near Phillip Island, Victoria. Mar Freshw Res 46:735-743

Hyatt AD, Hine PM, Whittington DA, Griffin DA, Bax NJ (1997) Epizootic pilchard mortality in the pilchard (Sardinops sagax neopilchardus) in Australia and New Zealand in 1995. II. Identification of the herpes virus in the gill epithelium. Dis Aquat Org 28:17-29

Jones JB (in press) In: Rodgers CJ (ed) Proceedings of the OIE International Conference on Risk Analysis in Aquatic Animal Health, Paris, France, 8-10 February, 2000. Office International des Epizooties (O.I.E.), Paris

Jones JB, Hyatt AD, Hine PM, Whittington DA, Griffin DA, Bax NJ (1997) Special topic review: Australasian pilchard mortalities. World J Microbiol Biotechnol 3:383-392

Lasker R (1985) An egg production method for estimating spawning biomass of pelagic fish: application to northern anchovy, Engraulis mordax. NOAA Tech Rep NMFS 36: 1-99

Lewis RK (1981) Seasonal upwelling along the south eastern coastline of Australia Aust J Mar Freshw Res 32:843-854

Lluch-Belda D, Crawford RJM, Kawasaki T, MacCall AD, Parrish RH, Schwartzlose RA, Smith PE (1989) Worldwide fluctuations of sardine and anchovy stocks: the regime problem. S Afr J Mar Sci 8:195-205

Lluch-Belda D, Lluch-Cota DB, Hernandez-Vazquez S, Salinas-Zavala CA (1991) Sardine and anchovy spawning as related to temperature and upwelling in the California current system. CALCOFI (Calif Coop Ocean Fish Invest) Rep 32:105-111

Lluch-Belda D, Hernandez-Vazquez S, Lluch Cota DB, Salinas-Zavala CA, Schwartzlose RA (1992a) The recovery of the Californian sardine as related to global change. CALCOFI (Calif Coop Ocean Fish Invest) Rep 33:50-59

Lluch-Belda D, Schwartzlose RA, Serra R, Parrish RH, Kawasaki T, Hedgecock D, Crawford RJM (1992b) Sar-

Editorial responsibility: George Humphrey (Contributing

Editor), Sydney, Australia dine and anchovy regime fluctuations of abundance in four regions of the world oceans: a workshop report. Fish Oceanogr 1:339-347

Lluch-Cota DB, Herandez-Vazquez S, Lluch Cota SE (1997) Empirical investigation on the relationship between climate and small pelagic global regimes and El NiñoSouthern Oscillation (ENSO). FAO Fish Circ 934:1-48

McGowan MF (1986) Northern anchovy, Engraulis mordax, spawning in San Francisco Bay, California. US Natl Mar Fish Serv Fish Bull 84:879-894

Middleton J (1995) The oceanography of Australian seas. In: Zann LP, Kailola P (eds) The marine environment. State of the marine environment report for Australia. Great Barrier Reef Marine Park Authority, Townsville, Queensland, p 1-10

Neira FJ, Miskiewicz AG, Trnski T (1998) Larvae of temperate Australian fishes. Laboratory guide for larval fish identification. University of Western Australia, Nedlands

Parrish RH, Serra R, Grant WS (1989) The monotypic sardines, Sardina and Sardinops: their taxonomy, distribution, stock structure, and zoogeography. Can J Fish Aquat Sci 46:2019-2036

Schwartzlose RA, Alheit J, Bakun A and 18 others (1999) Worldwide large scale fluctuations of sardine and anchovy populations. S Afr J Mar Sci 21:289-347

Smith PE (1973) The mortality and dispersal of sardine eggs and larvae. Rapp P-V Réun Cons Int Explor Mer 164: 282-292

Smith PE (1990) Monitoring inter-annual changes in spawning area of Pacific sardine (Sardinops sagax). CALVOFI (Calif Coop Ocean Fish Invest) Rep 31:145-151

Vouglitous JJ, Able KW, Hurtze RJ, Tighe KA (1987) Life history and population dynamics of the bay anchovy in New Jersey. Trans Am Fish Soc 116:141-153

Ward TM, Staunton-Smith J (in press) Comparison of the reproductive biology and spawning patterns of the sardine, Sardinops sagax, in temperate South Australia and subtropical southern Queensland. Fish Res

Ward TM, Kinloch M, Jones GK, Neira FJ (1998) A collaborative investigation of the usage and stock assessment of bait-fish in southern and eastern Australian waters, with special reference to pilchards (Sardinops sagax). Fisheries Research and Development Corporation, Canberra

Ward TM, Hoedt F, McLeay L and 6 others (2001) Effects of the 1995 and 1998 mass mortality events on the spawning biomass of sardine, Sardinops sagax, in South Australian waters. ICES J Mar Sci 58:865-875

Whittington RJ, Jones JB, Hine PM, Hyatt AD (1997) Epizootic pilchard mortality in the pilchard (Sardinops sagax neopilchardus) in Australia and New Zealand in 1995. I. Pathology and epizootilogy. Dis Aquat Org 28:1-15

Submitted: February 4, 2000; Accepted: November 15, 2000

Proofs received from author(s): September 9, 2001 